\title{
Multiple moulds
}

\section{カビが 3つ寄ってわかること}

André Goffeau

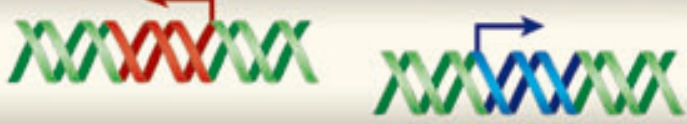

コウジカビ属の 3 種のカビのゲノム配列が解読された。これらのゲノムの比較から、カビが病原性と なったり、人間の役立つものになったりするのを決める要因など、いろいろなことが明らかになった。

Nature Vol. 438 (1092-1093) / 22 December 2005

菌類コウジカビ属 (Aspergillus) の 3 種のゲノム塩基配列 がNature2005 年 12 月 22/29 日号に報告された。日本で 酒造に利用されている銤（こうじ）菌（Aspergillus oryzae； コウジカビともいう) 1、ヒトの病原体である Aspergillus fumigatus $^{2}$ 、そして遺伝学のモデル種である Aspergillus nidulans ${ }^{3}$ の 3 つである。コウジカビ属は 185 種が知られて おり、その中にはヒト病原体が 20 種、植物病原体が多数、 そして食品や化学合成物質、産業用酵素の製造に使われる 多様な種が含まれる。今回解読された 3 種のゲノムから、カ ビの仲間の進化について、また、それぞれの種がもつ有益な、 あるいは有害な特性についてたくさんのことがわかってきた。

日本、米国、ヨーロッパ混成の研究チームが発表した 3 種の塩基配列は、平均して各ゲノムの $95 \%$ 近くをカバー している。3 種を合計すると、95 メガ塩基以上が配列解 読されたことになり、合わせて 24 本の染色体上には 3 万 3500 個以上のタンパク質コード遺伝子がぎっしり詰まっ ている (1 種につき染色体は 8 本)。これと比べて、ヒト ゲノムでは 3000 メガ塩基に対してタンパク質コード遺伝 子はおよそ 3 万個である。

銤菌は、日本で 1000 年ほど前から伝統的な発酵食品や 醸造酒の製造に使われてきた。趋菌ゲノム ${ }^{1}$ の DNA は $A$. fumigatus A. nidulans よりも約 $7 \sim 9$ メガ塩基多い。論 文著者たちはその理由を、他の種から㙞菌に、進化の過程 で遺伝子がいくつか移転したからではないかという。この 余分の DNA は䡒菌ゲノム全域に分散しており、そのおか げで、さまざまな二次代謝産物の合成や輸送にかかわる遺 伝子が豊富となっている。生物の正常な成長や発生、生殖 には直接的に関与しない物質である二次代謝産物は、1 種 か、せいぜいごく少数の種に特異的であることが多く、そ の種に固有の生理特性を知る手がかりとなる。
麹菌に近縁な Aspergillus flavus や Aspergillus niger (ク ロカビ）といった種は、同じような遺伝子を獲得してい る。たとえば有毒な A. flavus は、毒素アフラトキシンの 生成経路にかかわるタンパク質の遺伝子を 25 個もつてい る。これらの遺伝子は眚菌にもあるが発現はしない。どう やら、A. flavusの祖先がこれらの遺伝子を趜菌に受け渡し、 その後麹菌が進化していくなかで、これらの遺伝子が不活 性化されたらしい。

Aspergillus fumigatus はヒトを死に至らしめることもあ る病原体で、主要なアレルギー誘発物質（アレルゲン）で もある。A. fumigatus の塩基配列 ${ }^{2}$ から、これまで知られ ていなかった 9 種類のアレルゲン、特異的な二次代謝産 物の生成に関与する多数の遺伝子、そして、薬剤標的とな りそうな必須遺伝子の一群が見つかった。しかし、このカ ビの病原性を支える要因は複雑であり、それらを特定する にはゲノム解析を補完する他のアプローチも必要だ。たと えば、A. fumigatus が我々ヒトなど温血動物の体内で増殖 するには、(外界温度と比べて) 高い体温に耐えられなけ ればならない。これについては、DNA マイクロアレイ解 析を使って、 $37^{\circ} \mathrm{C} て ゙$ 活性が高まる一群の「温度耐性遺伝子」 が突き止められた。だが、このカビの病原性に関係するそ の他の多くの遺伝子にスイッチが入るには、 $37^{\circ} \mathrm{C} に$ 暖ま るだけでは不十分だとみられている。

Aspergillus nidulans は、菌類の遺伝学研究に長く使われ てきたモデル生物である。そのゲノム ${ }^{3}$ はコウジカビ属 3 種の比較解析に不可欠だったが、それ自体にも解明が待た れる特徵がいくつかあった。そして、数種類の遺伝子の調 節が明らかとなり、遺伝子の調節因子や制御要素が結合す ると思われる部位も見つかった。加えて、遺伝子の上流に ある短いオープン・リーディング・フレームも多数見つかっ 
た。これらの短い塩基配列は、隣り合う遺伝子の発現にブ レーキをかける可能性がある。さらにこのゲノムの塩基配 列からは、固有の代謝経路（脂肪酸酸化）や発生過程（極 性増殖)、DNA 修復経路にかかわる、まだ知られていなかっ た遺伝子が多数突き止められた。

今回解析された 3 種のカビは数億年前に枝分かれし、そ れぞれのゲノムは大きく異なっている ${ }^{3}$ 。3 種のゲノムの間 で非常に近い「相同」タンパク質はおよそ 3000 種類ある。 平均すると、こうしたタンパク質は 3 種すべてのゲノムに 存在する構成アミノ酸のうちの $68 \%$ にすぎない。この数 值は、約 4 億 5000 万年前に枝分かれした哺乳類と魚類の 間の相同タンパク質の率と同程度である。にもかかわらず、 染色体上の相同タンパク質遺伝子の並び順（シンテニー） は 3 種のカビで保存されており、進化の過程で全ゲノム重 複は起こっていないことがうかがわれる。しかし、小規模 な縦列反復配列や、染色体の端での遺伝子再配列、シンテ ニーブロックの少なからぬランダムな切断と再配列がある ために、大規模領域にわたるシンテニーはみられない。こ うしたゲノム再編成の程度は、A. fumigatusよりも麹菌の ほうが大きい。相同遺伝子内のアミノ酸進化の速度は 3 種 のカビすべてで同程度であることから、大規模な構造的再 配列の進化は、個々のカビのアミノ酸変化の速度と肩を並 べて起きたわけではないようだ。

また、カビ 3 種のゲノム比較解析から見つかった意外 な新事実は、A. fumigatus と麹菌の交配システムにある。 酵母菌の有性生殖は、交配型遺伝子によって決まる「交配 型」つまり「性」の異なる個体どうし間だけで起こる。 A. nidulans には 2 種類の交配型遺伝子があり、一方はア ルファボックスを含み、もう一方は高移動度群 (HMG) ドメインを含む。そのため、各細胞は同時に 2 つの性を もつことができ、A. nidulans は自家受精が可能だ。A. nidulans はまた、「有糸分裂による増殖」によって無性的 に増えることができ、分生子柄という構造の先端に胞子を 作ってまき散らす。

A. fumigatus と趜菌は、有糸分裂で無性的にしか増えな いと考えられていた。ところが意外なことに、今回解読 された䁍菌とA. fumigatusのゲノムでそれぞれ 1 個の交 配型遺伝子が見つかった。靝菌の塩基配列にはアルファ 交配型遺伝子が含まれ、一方、A. fumigatus の塩基配列に はHMG 交配型遺伝子が含まれていたのである。これらの 遺伝子はそれぞれのゲノム内でほぼ同一の位置を占めてお り、どちらの側にも 1.7 メガ塩基の保存されたシンテニー がある。さらに、A. nidulansの交配過程において別々の 段階で関与する 215 種類の遺伝子は、夈菌や A. fumigatus にもみられる。これらのデータや他の最近のデータ ${ }^{4}$ から、 A. fumigatus と麦匊菌が雌雄異体である可能性や、コウジカ ビ属の進化の過程で雌雄同体から雌雄異体への転換が起 こった可能性が出てくる（図 1)。

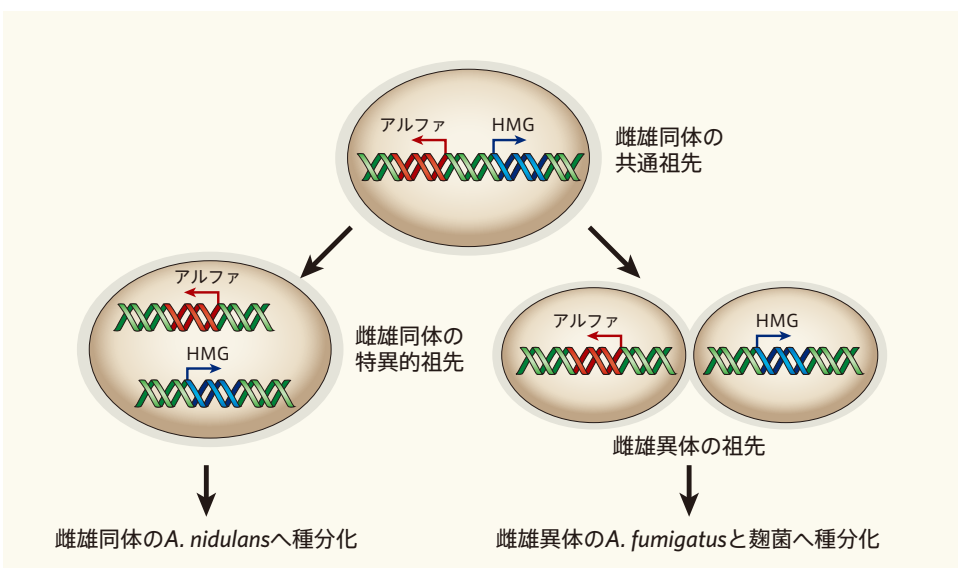

図 1 コウジカビ属の交配型遺伝子の進化モデル。雌雄同体の共通祖先では、アル ファ (赤色) と HMG（青色）の 2 つの交配型遺伝子が同一染色体上に前後して並 び、類似した隣接する調節領域（緑色）を共有している。雌雄同体の A. nidulans で は、染色体が切断され、2つの交配型遺伝子は違う染色体にそれぞれ隣接領域を伴っ て分かれた状態となる。鍻菌とA. fumigatus の祖先では、2 つの交配型遺伝子は分 離して別々の株に入るが、隣接する遺伝子群は似通ったままである。種分化を経て $A$. fumigatus も趜菌も完全に雌雄異体となり、アルファ交配型のみをもつ株か HMG 交 配型のみをもつ株かになるが、そのどちらも染色体環境は似通っている。

今回の研究報告はもちろん、カビ 3 種のゲノムを解析 した初めてのものであって、得られたゲノム塩基配列情報 からは今後のさらなる解析が待たれる。コウジカビ属内の 他種のゲノム塩基配列解読も現在進んでおり、そちらの成 果が上がれば、コウジカビ属の生物学的特性や進化に関し てもつと幅広い情報をつかめるはずだ。なかでも塩基配列 解読に最も熱い期待が寄せられているのが、クエン酸製造 に長年利用されてきたクロカビ A. nigerである ${ }^{\circ}$ 。コウジ カビ属のクロカビも含めたいくつかの種は商業的に重要な 価值があるために、それらのゲノム塩基配列に対してはこ れまで長くバイオテク企業がその門戸を閉ざしてきた。し かし、この慣例も変わりつつあるようだ。日本の醸造企業 の共同研究組織は麹菌の塩基配列の公表に同意し、モンサ ント社は自社の A. nidulans ゲノム塩基配列へアクセスで きるようにしてくれた。そのおかげで、これらのゲノムも 今回、公的資金で解析された他の塩基配列のグループに仲 間入りできたわけだ。そして、米国エネルギー省は産業用 に使われるクロカビ A. niger の塩基配列を完全に読み取り (現在のものはカバー度が低い)、このゲノムの有用版を公 表するとしている。ゲノム塩基配列情報を業界の中だけに 囲い込む時代は、どうやら終わりを告げたようだ。

ルーヴァン・カトリック大学 (ベルギー)、AndréGoffeau

1. Nierman, W. C. et al. Nature $438,1151-1156$ (2005).

2. Machida, M. et al. Nature 438, 1157-1161 (2005).

3. Galagan, J. E. et al. Nature 438, 1105-1115 (2005)

4. Paoletti, M. et al. Curr. Biol. 15, 1242-1248 (2005).

5. Hennebert, G. L. Recueil de Travaux d'Histoire et de Philologie 6, 61-103 (Univ. Louvain, 1979). 